\title{
MASTER
}

\section{Some Perspectives on Energy \\ Conservation Outreach Programs}

July 1978

Published

October 1978

U.S. Department of Energy

Assistant Secretary for Intergovernmental

and Institutional Relations

Office of Intergovernmental Affairs

Energy Extension Service
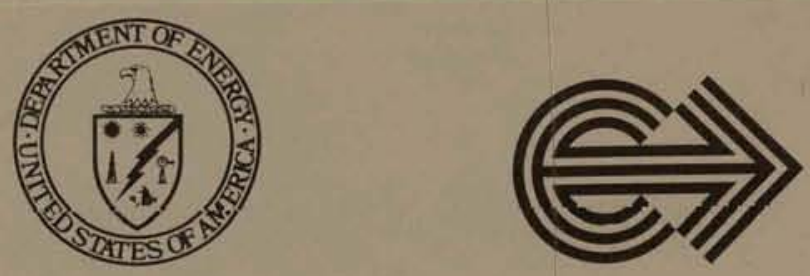


\section{DISCLAIMER}

This report was prepared as an account of work sponsored by an agency of the United States Government. Neither the United States Government nor any agency Thereof, nor any of their employees, makes any warranty, express or implied, or assumes any legal liability or responsibility for the accuracy, completeness, or usefulness of any information, apparatus, product, or process disclosed, or represents that its use would not infringe privately owned rights. Reference herein to any specific commercial product, process, or service by trade name, trademark, manufacturer, or otherwise does not necessarily constitute or imply its endorsement, recommendation, or favoring by the United States Government or any agency thereof. The views and opinions of authors expressed herein do not necessarily state or reflect those of the United States Government or any agency thereof. 


\section{DISCLAIMER}

Portions of this document may be illegible in electronic image products. Images are produced from the best available original document. 
Available from:

National Technical Information Service (NTIS) U.S. Department of Commerce

5285 Port Royal Road

Springfield, Virginia 22161

Price: Printed copy: $\$ 6.00$

Microfiche: $\quad \$ 3.00$

For sale by the Superintendent of Documents, U.S. Government Printing Office

Washington, D.C. 20405

Stock No, 061-000-00197-2 
DOE/IR-0034

Dist. Category UC-13

\section{Some Perspectives on Energy Conservation Outreach Programs}

July 1978

Published

October 1978

Authors:

Alfred Schwartz, Evaluation Coordinator, DOE James H. Baroff, Energy Policy Consultant

U.S. Department of Energy

Assistant Secretary for Intergovernmental and Institutional Relations

Office of Intergovernmental Affairs

Energy Extension Service

Washington, D.C. 20585
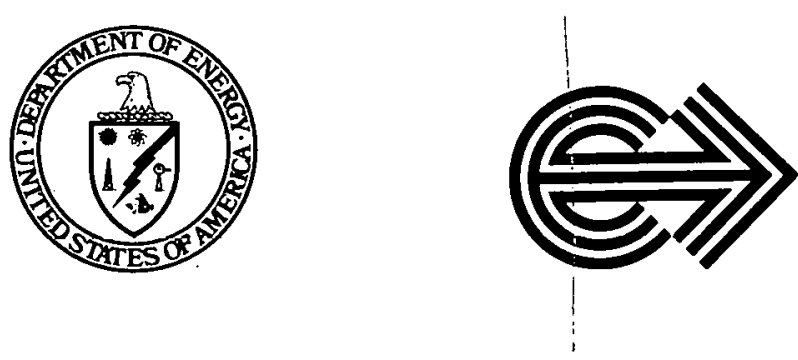

This repon was prepared as an account of work sponsored by the United States Government. Neither the United States nor the United States Department of Energy, nor any of their employees, nor any of their contractors, subcontractors, or their employees, makes any warranty, express or implied, or assumes any legal liability or responsibility for the accuracy, completeness or usefulness of any information, apparatus, product or or usefulness of any information, apparatus, product or
process disclosed, or represents that its use would not process disclosed, or represents
infringe privately owned rights.

L. 


\section{ACKNOWL EDGMENTS}

More than 30 representatives of Federal and state agencies, utility companies, and public interest groups provided information for this report and sérved as reviewers. Many of those persons are referenced in the. text. The draft was also reviewed by 20 additional contributors whose, " '! helpful comment's were Included and much appreciated by the authors.

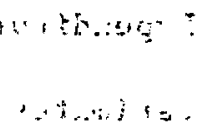

$\because x+y)=$

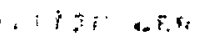


ABSTRACT

Most government and selected private sector energy conservation outreach programs are reviewed and summarized, notably those that have features in common with the Energy Extension Service of the US Department of. Energy.

Expenditures for FY 1978 are tabulated for major government programs, and estimates of per capita expenditures by public and private electric and gas utilities in the field of energy conservation are made.

In the ten Energy Extension Service pilot states, funding amounts to $\$ 0.69$ per capita while utility company conservation efforts average $\$ 0.95$ per capita.

There is an estimated total of $\$ 100$ million annually spent for energy outreach in FY 1978, in the 10 pilot states (in which 54 million people reside). Of this figure $\$ 37$ million is being spent by all Federal agencies, of which the Energy Extension Service accounts for approximately $\$ 9$ million. 
TABLE OF CONTENTS

Acknowledgments

Abstract

A. Introduction

B. Conclusions

C. Federal and State Outreach Budgets

D. County and Local Government Outreach Budgets

E. Private Sector Outreach Budgets

F. Electric and Gas Private Utility Surveys

Appendix A

51

LIST OF FIGURES

1: Federally Supported Energy Outreach

10 Activities and Budgets for FY 1978

2. Weatherization Component of Outreach Budgets for FY 1978

3. Department of Energy (DOE) - Energy Policy and Conservation Act/Energy Conservation and Production Act - (EPCA/ECPA)

4. Per Capita Analysis of Federa1/State Energy Conservation Outreach

5. Example Cities in EES Pilot States Active in Energy Conservation

6. Gas Utilities with Energy Outreach Activities

7. Energy Outreach Staff Expenditures by Electric Utilities

8. Summary of Electric and Gas Utility Outreach Surveys 
SOME PERSPECTIVES ON ENERGY CONSERVATION OUTREACH PROGRAMS

by

Alfred Schwartz, Evaluation Coordinator, Energy Extension Service U.S. Department of Energy

James H. Baroff, Consultant, The Energy Center, Washington, D.C.

\section{A. INTRODUCTION}

This is a summary of major government and private-sector sponsored energy conservation outreach activities in the 10 Department of Energy Extension Service Pilot States ${ }^{*}$ for FY $1978 .^{* *}$ It is limited to types of outreach activities provided by Energy Extension Service (EES) programs, the most common of which are hotlines, audits, and workshops (including seminars and training sessions). Although government-sponsored activities are quite thoroughly treated, non-government activities are not. Energy conservation outreach activities surveyed in the private sector are limited to privately-held gas and electric public utility. company initiatives.

\section{Objectives of This Paper}

1. To permit EES and its evaluation contractor staff to view EES in perspective for Federal evaluation purposes by providing an understanding of other similar outreach activities in the Federal, State, local government and private sectors. The ability to separate the level of EES activity from all other similar and overlapping

${ }^{\star}$ Alabama (AL), Connecticut (CT), Michigan (MI), New Mexico (NM), Pennsylvania (PA), Tennessee (TN), Texas (TX), Washington (WA), Wisconsin (WI), Wyoming (WY).

${ }^{\star *}$ The Federal Fiscal year, Oct. 1, 1977- Sept. 30, 1978. 
activities will permit the development of a rough measure of the efficiency and effectiveness of EES outreach activities in comparison with the aggregate of all other activities, including a measurement of actual Btu savings and conversions to renewable energy resources. The client/non-client surveys that will be performed by the evaluation contractor to DOE will provide impact information for such an analysis.

2. To provide Congress with a perspective on the total national energy conservation outreach picture based on a sample of 10 pilot States representing 25 percent of the total U.S. population.

3. To permit each pilot EES State to visualize its own efforts in perspective and to aid in further identifying similar State programs for operations planning purposes and for developing an Information sharing network.

4. To assist other Federal agencies within and outside of DOE in understanding the groups involved in energy conservation outreach and their levels of effort.

5. To provide a model for developing a similar national study of all States for the expanded National Energy Extension Service, which is scheduled to begin in April 1979.

\section{Scope and Limitations}

This perspectives paper identifies Federal, State, local government and private energy outreach activities, but detailed funding information is 
presented only for. Federal and related State inftiatives. Amounts listed for Federally sponsored programs include State contributions to those programs (See Figures $1-4$ on pages 10-13).' Although specific and complete cost data for the remaining areas (regional groups, counties, cities and utility companies) was not available, known non-Federal activities within the pilot States are discussed along with an Indication of the types of services provided. Expenditures by six electric and three gas utility outreach programs surveyed by telephone are also included in Section $F$.

Summary results exhibited in this paper present neither the status of county initiated activity nor the full extent of activities in the nongovernment sector. The latter are represented predominately by major outreach activities of the utility companies.

\section{B . CONCLUSIONS}

- Total Federal Government initiatives including State contributions and DOE/EES in 1978 are budgeted at $\$ 37,107,000$ (See Figure 1). of this Federal total: DOE $=41.5 \% *$ EES $=24.9 \%$.

- Energy Extension Service funds, as a proportion of total Federal outreach funds (Including EES), vary widely from one pilot state to another. The range is from 15 percent for EES in Pennsylvania to

* This figure consists of $\$ 13.7 \mathrm{M}$ from the eighth line of Figure 1 plus the DOE outreach component in the first line of Figure 2, of $\$ 1.7 \mathrm{M}$. 
48 percent in Wyoming (see Figure 4). Examples of average per capita allocations are shown below. (These ratios apply to the population of each State as a whole even though individual extension service activities may be directed to a target audience which is only a subset of total State population.)

Total Outreach Dollars per capita (FY 1978)**

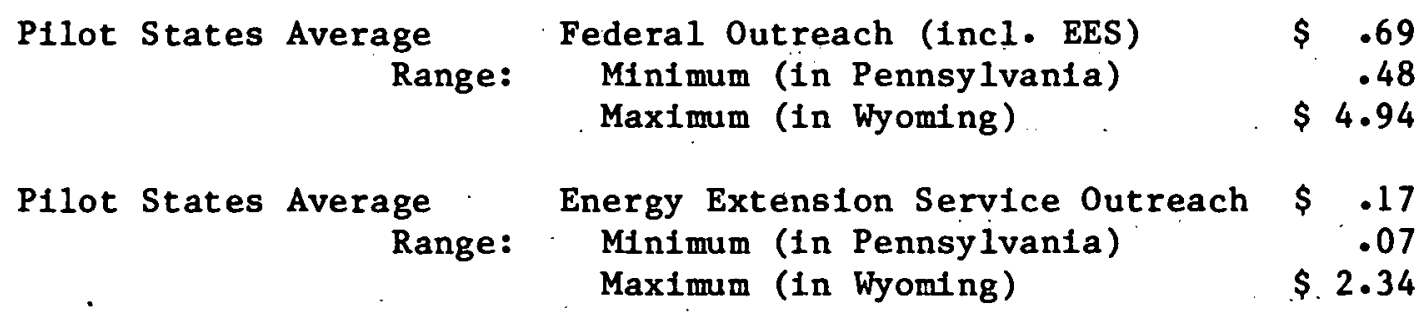

- Amounts expended by county and local governments within the pilot States for non-Federally inftiated energy outreach activities are believed to be small compared with those of Federally initiated government programs in the pllot States. However there is activity In practically every state.

For example, based on preliminary information on cities it: is estimated that where c1ty outreach programs exist, the total amount expended is at least $\$ 100,000$ per State. Cities in only six of the ten pilot States were reported to have significant independent energy

** Based on total State populations (1975 Census estimates). 
conservation outreach programs. Their activity is likely to be rélated to energy audits of city buildings and lighting efficiency méàsures.

- A crude initial estimate, only an educated guess, of total nongovernment expenditures today for energy conservation outreach activities in the 10 pilot states combined exceeds $\$ 60,000,000$, almost twice the Federal and State expenditures combined. This amount would include privately-held pubilc utility company efforts of about $\$ 1$ per capita, plus those of ofl companies, energy and environmental awareness groups and small businesses in providing information on heating, cooling, retrofitting and alternate energy sources. Estimated expenditures are for information services only and exclude consideration of materials and labor costs associated with installation. However, as electric utilities expand their conservation programs, even larger total expenditures can be anticipated.

- Assuming the private sector estimates above are reasonable, the total amount expended for all government and non-government outreach activities combined is approximately $\$ 100$ million or $\$ 1.85$ per person in the ten pilot EES States. These expenditures excluded those of county governments because the amount of such expenditures are unknown at this time. 
- On the average, for the 10 pilot States, EES provides approximately. nine percent of al1 est1mated government and non-government energy outreach funding combined, for an equivalent annual budget colnciding approximately with FY 1.978 . 


\section{FEDERAL AND STATE OUTREACH BUDGETS}

The Comprehensive Program and Plan (CPP) for Federal Energy Education, Extension and Information Activities* describes a total of 63 programs throughout the Federal establishment, which touch upon energy conservation and renewable fuels. One purpose of this. paper is to extract from that larger array of programs, a subset which overlaps the outreach activity of the DOE Energy Extension Service (EES). Those programs selected are further analyzed in terms of FY 1978 budget commitments. The results of the analysis are displayed in Figure 1 which should be read together with its accompanying notes.

For purposes of this paper, an outreach program was retained only if it met three criteria:

(a) There is two-way direct communication between program staff and the public.

(b) The target audience consists of members of residential households or small businesses.

(c) Energy conservation or the use of renewable fuels plays a dominant role in the program subject matter.

At the present time, weatherization programs constitute by far the largest expenditure of Federal funds for conservation. In fact, in every

* Department of Energy Publication DOE.IR/005 (February 1978). 
one of the extension States, the combined funding of the DOE weatherization program and the Community Services Administration (CSA) program far exceeds the Federal and State conservation efforts due to all other. programs, including EPCA/ECPA and EES itself. Since the inclusion of total weatherization expenditures would distort any relative comparison among programs, weatherization has been treated separately (see Figure 2). Costs of materials, transportation of materials, personnel costs and all labor associated with installation of weatherization materials (Including labor contributed under the Department of Labor Comprehensive Employment and Training Act (CETA) program) have been eliminated from the weatherization conservation outreach line item in Figure 1. It is interesting to note, nevertheless, that for every dollar spent for insulation materials, a second dollar is required in the form of labor. This one-for-one matching rule holds for both the DOE and the CSA funded weatherization programs.

For the DOE EPCA/ECPA programs, only those activities have been selected which have a direct outreach component. The detailed DOE EPCA/ECPA subproject computer runs were analyzed for each of the ten EES States. Subprojects, such as thermal efficiency standards, which are not $100 \%$ outreach but which have some outreach component were retained in total, since there was no simple accounting technique for further refining the data. Details of the EPCA/ECPA activities by state and subject matter are displayed in Figure 3. These budget amounts include State contributions, so that the ECPA/ECPA line 1tem in Figure 1. must be viewed 
as a combined Federal/State outreach figure. Weatherization programs which were reported to the EPCA program office by the States have been excluded in Figure 3 to avoid double counting.

All programs within the Comprehensive Program and Plan (CPP) which qualify according to the three criteria listed above, but which are less than $\$ 130,000$ annually for all 50 States, have been summed into the category "Minor Federal Programs" in Figure 1. They constitute a negligible fraction of total funding.

For a narrative description of each line item listed in Figure 1 , the reader is referred to the CPP document itself. References to Appendix $A$ of that report are given in the first column of Figure 1. Copies of the pages referenced are attached as Appendix A, pages 51 through 91 of this paper, with a tabulation of programs appearing on pages $52-53$. 
FIGURE 1

FEDERALLY SUPPORTED ENERGY OUTREACH

ACTIVITIES AND BUDGETS FOR FY 1978

(In Thousands of Dollars)

By Program for each EES State

CPP*

\begin{tabular}{|c|c|c|c|c|c|c|c|c|c|c|c|c|c|}
\hline Reference & Program Description & Notes & AL & CT & MI & NM & PA & TN & $\mathbf{T X}$ & WA & WI & WY & $\begin{array}{l}\text { In EES } \\
\text { States }\end{array}$ \\
\hline \multicolumn{14}{|c|}{ DOE PROGRAMS } \\
\hline $\begin{array}{l}A-2 \\
A-4\end{array}$ & $\begin{array}{l}\text { Conservation Education Programs } \\
\text { Solar Technology Transfer }\end{array}$ & & 3 & 3 & 9 & $\begin{array}{r}1 \\
40\end{array}$ & 11 & $\begin{array}{r}4 \\
40\end{array}$ & 11 & $\begin{array}{r}3 \\
40\end{array}$ & 4 & 1 & $\begin{array}{r}50 \\
120\end{array}$ \\
\hline$A-13-1$ & Appropriate Technology Grants & & & 100 & 100 & & & .0 & & & 100 & & 300 \\
\hline$A-13-2$ & Conservation Technology Transfer & & & 10 & & & & 50 & & & & & 60 \\
\hline$A-22$ & EPCA/ECPA (Figure 3) & (1) & 643 & 642 & 1240 & 593 & 2157 & 935 & 3515 & 430 & 1750 & 785 & 12,690 \\
\hline $\begin{array}{l}A-32 \\
A-34-35\end{array}$ & $\begin{array}{l}\text { Project Conserve } \\
\text { Academic and public programs }\end{array}$ & (2) & 21 & 18 & 54 & 7 & 69 & 25 & 72 & 21 & 27 & 2 & 316 \\
\hline . & SUBTOTAL - DOE ... & (3) & $\frac{9}{676}$ & $\frac{7}{780}$ & $\frac{22}{1425}$ & $\frac{3}{644}$ & $\frac{28}{2265}$ & $\frac{10}{1064}$ & $\frac{29}{3627}$ & $\frac{8}{502}$ & $\frac{11}{1892}$ & $\frac{1}{789}$ & $\frac{128}{13,664}$ \\
\hline
\end{tabular}

FEDERAL AGENCIES (MAJOR PROGRAMS OTHER THAN DOE AND WEATHERIZATION)

A-11

A -51

A-52

A-50

A-87

A-87

A-87

A-97

A-97

A-73-77

A-94

A-63-71

FEDERAL WEATHERIZATION OUTREACH (From F1gure 2)

MINOR FEDERAL PROGRAMS (A 41, A 44-45, A 77, A 86)

TOTALS (excluding DOE/EES)

ENERGY EXTENSION SERVICE (EES) (A-46).
DOC - EADC

DOC - Technical Assistance.

DOC - University Centers

- Solar Demonstrations

UD - Franklin Institute

CSA - Consumer Infor. \& Educ.

USDA - Cooperative Extension

ACTION/VISTA \& University Year

EPA - Auto Fuel Economy

TVA - Various

(4)

(5)

(6)

(7)

$\begin{array}{r}7 \\ 35 \\ 50 \\ 130 \\ 28 \\ 233 \\ 17 \\ 23 \\ 706 \\ 234 \\ 4 \\ \hline 2143 \\ \hline\end{array}$

1,003

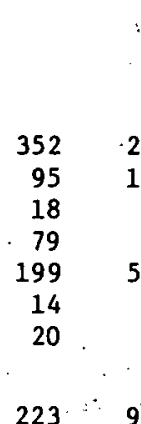

50

$\begin{array}{rrrr} & 30 & 30 & \\ 25 & & & \\ 7 & & 7 & 7 \\ 228 & 262 & 36 & 488 \\ 30 & 28 & 6 & 245 \\ & 49 & 15 & 13 \\ 74 & 755 & 270 & 788 \\ 5 & 56 & 20 & 57 \\ 7 & 75 & 27 & 77 \\ & & 824 & \end{array}$

2

97
160
400
296
22
29

60

50

$\varpi$

*Comprehensive Program and Plan for Federal Energy Education, Extenston and Informat1on Activit1es; DOE/IR-005 (Feb. 1978). 
FIGURE 2

WEATHERIZATION COMPONENT OF OUTREACH BUDGETS FOR FY 1978

(In Thousands of Dollars)

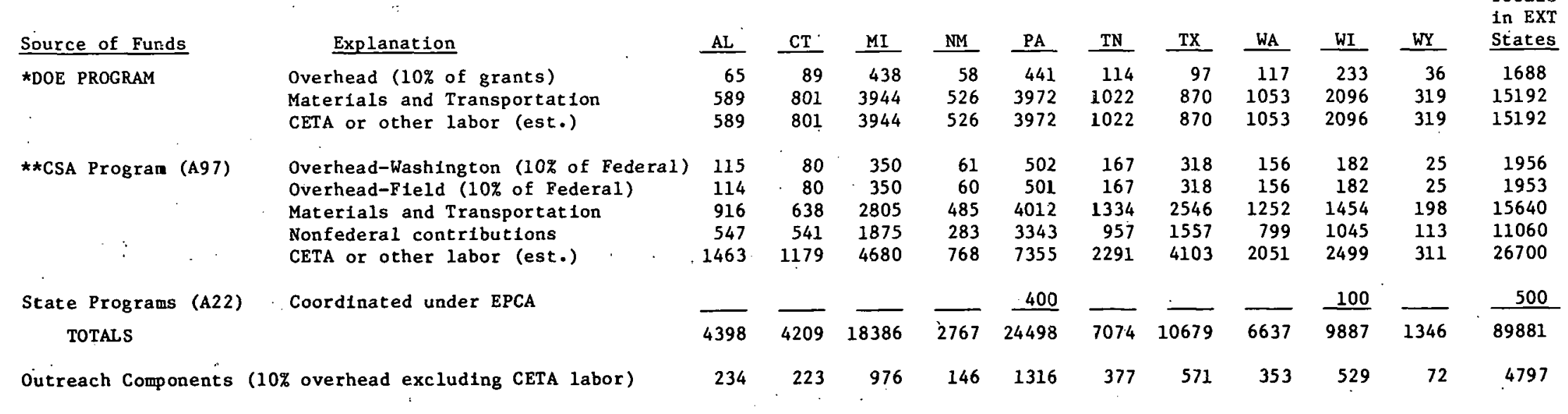

* Data provided by Mary Bell, DOE; Conservation and Solar Applications, Office of Weatherization Assistance.

** Data provided by Mr. Richard Saul, CSA, from national transaction computer printout "Energy Programs - PAC GR4." 
FIGURE 3

DEPARTMENT OF ENERGY - EPCA/ECPA OUTREACH BUDGETS FOR FY 1978

$$
\text { (In Thousands of Dollars) }
$$

(Includes State and other matching funds)

\section{EPCA Program}

Thermal Efficiency Standards

Lighting Efficiency Standards

Transportation

Residentlal Houses

Commercial

Project Conserve

Recycling.

Waste 011

Technology - Small Business

Agriculture

Natural Gas Conservation.

Information and Education

Subtotal EPCA Outreach

ECPA Supplementa1

\section{Energy Audits}

Public Education

Subtotal ECPA Outreach

TOTAL EPCA/ECPA (For line A22-Figure 1)

$$
\text { AL } \mathrm{CT} \text { MI } \stackrel{\mathrm{NM}}{\mathrm{PA}}
$$

TN TX WA WI WY

\begin{tabular}{rrrrrrrrrr}
75 & 63 & 15 & - & 200 & 40 & 33 & 34 & 140 & 30 \\
30 & 45 & - & - & 90 & - & 63 & - & - & - \\
80 & 89 & 95 & - & 400 & 115 & 69 & 39. & 260 & 5 \\
15 & 107 & 50 & 328 & 42 & 123 & 2947 & 111 & - & 415 \\
50 & 49 & 113 & 128 & - & 240 & 600 & 95 & 1063 & 49 \\
90 & - & 305 & - & - & 35 & - & - & - & - \\
30 & 5 & 50 & - & - & - & - & 9 & - & - \\
- & 4 & 20 & 14 & 45 & - & - & - & 8 & - \\
- & - & 165 & - & - & - & - & - & - & - \\
- & - & 67 & 14 & 300 & - & 100 & 7 & 20 & 151 \\
- & - & - & - & 380 & - & - & - & - & - \\
55 & - & - & - & - & 90 & - & 29 & - & - \\
\hline 425 & 362 & 880 & 484 & 1457 & 693 & 2912 & 324 & 1491 & 650
\end{tabular}

* Data not avallable. 
FIGURE 4

PER CAPITA ANALYSIS OF FEDERAL/STATE ENERGY CONSERVATION OUTREACH

\section{FY 1978}

Totals - Federal/State programs other than EES (From Figure 1, $\$ 000$ )

DOE Extension Service Funding $(\$ 000)$ (See note 7 )

EES + Other Federal/State

EES/(EES + other)

Populations (Thousands, 1975)

Non-EES Funding (\$/person)

EES Funding ( $\$ /$ person)

Total Federal/State Funding ( $\$ /$ person)

$\begin{array}{rrrrrrrrrrrrrr}\text { AL } & \text { CT } & \text { MI } & \text { NM } & \text { PA } & \text { TN } & \text { TX } & \text { WA } & \text { WI } & \text { WY } & \begin{array}{c}\text { Totals } \\ \text { in EES } \\ \text { States }\end{array} \\ 2143 & 1784 & 3632 & 1167 & 4849 & 2681 & 5887 & 1322 & 3430 & 971 & 27,866 \\ 1003 & 992 & 861 & 880 & 880 & 8 B 0 & 1114 & 880 & 874 & 877 & 9,241 \\ 3146 & 2776 & 4493 & 2047 & 5729 & 3561 & 7.001 & 2202 & 4304 & 1848 & 37,107 \\ 31.9 \% & 35.7 \% & 19.2 \% & 43.0 \% & 15.4 \% & 24.7 \% & 15.9 \% & 40.0 \% & 20.3 \% & 47.5 \% & 24.9 \% \\ 3614 & 3095 & 9157 & 1147 & 11827 & 4188 & 12237 & 3544 & 4607 & 374 & 53,790 \\ .59 & .58 & .40 & .1 .02 & .41 & .64 & .48 & .37 & .74 & 2.60 & .52 \\ .28 & .32 & .09 & .77 & .07 & .21 & .09 & .25 & .19 & 2.34 & .17 \\ .87 & .90 & .49 & 1.79 & .48 & .085 & .57 & .62 & .93 & 4.94 & .69\end{array}$


NOTES TO FIGURE 1

1. EPCA/ECPA state totals include State and other non-Federal contributed funds as reported by the States. Weatherization subprograms, even though they may relate to a State EPCA office, are reported separately under weatherization. Detalls of EPCA/ECPA are shown In: Figure 3.

2. There are additional Project Conserve activities under EPCA, in AL, MI and TN (see Figure 3).

3. Not counting DOE contributions under weatherization (see Figure 2).

4. Including non-Federal matching funds provided by States or local governments.

5. A complete breakout of weatherization programs appears in Figure 2, including approximate CETA labor contributions.

6. Included are other smaller outreach programs, which appear in the CPP. These are specifically:

A41 DOE Publications

A44 DOE Office of Public Affairs - Press Relations

A45 DOE Office of Public Affairs - Special Programs

A77 ACTION/VISTA Youth Challenge Program

A86 HUD-Product Dissemination and Transfer Program

None of these individual programs exceeds $\$ 130,000$ on a national basis. 
7. The total of the EES grant funding plus State voluntary contributions cover the 19-month period starting at the time of award in September 1977 and ending in March 1979. However, little if any, activity began in the pilot states during the first quarter of FY 78 (October $\because 1977$ - December 1977). The budgeted amounts, then, apply to the 15-month period January 1978 through March 1979, In order to place the EES funding in perspective, in comparison to other ongoing FY 78 activities, twelve-fifteenths of the total EES grant funds are used in Figure' One. 
ADDITIONAL NOTES TO FIGURE ONE BY LINE ITEM

A-2 Total CPP estimate allocated by population to EES states.

A-4 $\$ 120,000$ outreach activity prorated to three National Laboratories, Los Alamos, NM; Oak Ridge, TN; and Pacific Northwest, WA. (Personal communication, Lawnie Taylor, DOE)....

A-13-1 Projected pro rata shares of grant program forthcoming in Midwest and then Northeast. Present program in Western States does not overlap EES States (Personal communication, Jerry Duane, DOE/CSA/BCS).

A-13-2 Specific outreach contracts (Personal communication, Jerry Duane, DOE), League of Women Voters weatherization project in Connecticut, and Texas A\&M outreach.

A-22 "See Figure 3 for details. EPCA/ECPA data were taken from computer listings of State Energy Conservation Plan detalls, provided by Gail McKinley, DOE/CSA/Office of State and Local Programs. Figures are DOE grants to the States plus contributed State funds.

A-32 Project Conserve CPP total of $\$ 1.25$ million is prorated to each EES State, proportional to population. Alabama, Michigan and Tennessee have incorporated Project Conserve into their EPCA plans as we11. 
A-34-35 Portion of DOE Educational Division funds used to reach out directly to the public. Funds available directly to educational institutions are excluded. (Personal communication, Donald Duggan, DOE).

A-50 $\because$, . There is a total of 20 university programs with total funding of $\$ 150,000$. (Private communication - Glen Fatzinger, DOC).

A-51: Est1mated outreach programs in Gillette, Wyoming (on boom towns) and colleges in Michigan (Personal Communication - Al Diamond, DOC/EDA).

A-52 Multicounty professional service energy grants (Personal communication - Bernhard Richert, DOC/EDA).

A-63-72 Outreach budgets from various programs in CPP totalling $\$ 3.284$ million have been prorated to TVA service area States by population. Tennessee accounts for $25.1 \%$ and Alabama $21.8 \%$. (Other TVA States are $\mathrm{NC}$ and $\mathrm{KY}$ ).

A-73-76 Combined ACTION/VISTA and University Year programs. CPP figures have been allocated to each state according to population.

A-87 Data provided by Mike Lenzi using HUD computer printouts of specific solar demonstration grants totalling $\$ 17$ million 
in all States. Franklin Institute National Solar Heating and Cooling Information Center's $\$ 5$ million annual budget has been prorated according to frequency of inquiries in the EES States (Personal Communication Jerry Mara NSHCIC 215/448-1322) - Total inquiries for the 11 -month period $10 / 1 / 76$ to $9 / 30 / 77$ were 165,000 from all States, including Hotine and ma11.

A-94 ' \$1.35 million EPA program, mechanized mainly through auto: dealers to the public, prorated to each State according to population.

A-95 Estimates based on prorata distribution to EES States by 1975 population figures, using total CPP National Energy activity of $\$ 13.7$ million. 
Outreach Budget Analysis

Figure 4 is an analysis of Energy Extension and other Federal and State outreach activities in the ten extension states, on a per capita basis, using 1975 population figures.

As shown on line 4 of Figure 4, EES funding ranges from a low of about 16 percent in the populous states of Pennsylvania and Texas to a high of 48 percent in sparsely populated Wyoming. This is due to the fact that. many of the other activities are funded on a per capita basis, while EES funding is relatively constant for each State. It indicates that Wyoming should be a likely state in which to expect conservation results which can be more easily attributable to the EES experiment. This conclusion needs to be refined to take into account the actual sizes of target audiences to whom EES funds are directed. Some State EES programs may reach the total State population as a whole while other State programs reach out on a selective basis only.

The average budget. for all Federal-plus-State programs excluding EES is 52 cents per person, ranging from a low of 40 cents in Michigan to a high of $\$ 2.60$ in Wyoming.

Total funding, including EES, ranges from a low of 48 cents per capita In Pennsylvania to $\$ 4.94$ per capita in Wyoming, with an average of 69 cents per person in the ten pilot States. 
D. COUNTY AND LOCAL GOVERNMENT OUTREACH BUDGETS

The National Association of Counties surveyed its members in order to be in a position to report energy conservation programs at the county level in the ten pilot States. It is also known that certain California counties and Anne Arundel County in Maryland, and présumably many more of the 3,000 U.S. counties as well, have established citizen advisory committees for energy conservation. Comprehensive information about the extent of the local situation nationwide, and of budgets associated with county conservation programs are not available. Selected details, however, are avallable and reported here.

Local government energy conservation outreach activities in a sampling of the pilot States are highlighted next.

Alabama: Nineteen counties have participated in the relatively new "Centsable Action" energy program to audit and recommend improvements in county buildings. The program was sponsored by the Association of County Commissions in Alabama and conducted by representatives of the Alabama Power and Light Company. According to a utility representative, all of the counties are acting on the recommendations and w111 expend county funds to make the necessary improvements.

Michigan: Interest in energy conservation in Michigan is high, and numerous counties have begun outreach programs. Macomb County spent $\$ 160,000$ to install a solar system in a county services bullding; Oakland County estimates that $\$ 50,000$ was spent on in-house, outreach, 
and solar feasibllity efforts; Bay County and Genesee County each expended approximately $\$ 15,000$ on outreach efforts including home audits and copsumer education. Ingham County has had an energetic energy conservation effort since 1973, Including niumerous outreach services, solar bulldings, and government programs.

Pennsylvania: .. Allegheny County has contriputed approximately $\$ 50,000$ of county funds for comprehensive energy conservation programs. York County spent approximately the same amount on a solar-heated nature center. As in other states, Pennsylvania counties have contributed tax monies to their regional planning commissions, and some of these funds have been used by the planning commission's energy information and planning activities.

Tennessee: The Metropolitan Government of Nashville-Davidson County has been involved in energy conservation since 1973. Although not purely an outreach expenditure, it is noteworthy that the combined city and county allocated $\$ 3$ million to retrofit public schools and $\$ 40,000$ for a computerized bullding magement system. Sullivan County recently estrablished an energy office, and allocated approximately $\$ 18 ; 000$ to hire an energy coordinator to direct the effort. 
Texas: Galveston County has contracted with a computer for a bullding management, program, and Harris County has active weatherization and carpooling programs. San Saba and San Antonio Counties individually note that they have expended county general funds on In-house and weatherization programs, but did not indicate the amounts.

Wisconsin: Milwaukee County has had an active energy conservation program for several years. It recently, budgeted $\$ 75,000$ in operating funds and $\$ 445,400$ in capital funds (not classified as outreach) for weatherization of county bulldings, solar demonstrations, carpooling, and consumer information efforts: Brown County estimates a "county contribution of $\$ 8,000$ in energy outreach efforts:

There are Economic Development Districts made up of several local governments active at the multi-county regional level, which are members of the National Association of Regional Councils. As organtzations of local government, regional councils have developed long-range as well as short-range energy plans that can be utilized by local governments, businesses and citizens to increase the efficient use of energy $\bullet:$ This Washington D.C.--based association consists of 331 members, out of a total of 650 cooperative combinations of county and city governments, which, however, are not government units in themselves. According to a survey conducted in the fall of 1977,50 regional councils had an energy component in their activities.. The Washingt on Metropolitan Counc11 of Governments ("COG") is one such example. 
Those commissions and councils involved in energy conservation in the EES Pilot States are:

1. Southeast Alabama Regional Planning and Development Commission P.0. Box 1406 - Suite 207,'Plaza 2

Dothan, Alabama $36301 \quad 205 / 794-4092$

2. First Tennessee - Virginia Development District

207 North Boone Street

Johnson City, Tennessee 37601

$615 / 928-0224$

3. Middle Rio Grande Development Council

P.0. Box 1461

Del Rio, Texas 78840

$512 / 775-1581$

4. Permian Basin Regional Planning Commission P.0. Box 6391

Midland, Texas 79701

$915 / 563-1061$

5. Nortex Regional Planning Commission

1914 Kemp Boulevard

Wichita Falls; Texas 76309

$817 / 322-5281$

6. Klickitat Regional Council

P.0. B.ox 268

Golendale, Washingț on 98620

$509 / 7,73-5703$

With respect to city government, energy conservation outreach information was obtained from Ms. Fredie Diane Kay on the Energy Staff of the U.S. Conference of Mayors (USCM). 
The USCM, headquartered in Washington, D.C., represents larger cịties whose populations tend to be greater than 30,000; the National League of Cities is generally devoted to smaller cities. Conservation outreach by the small cities is reported to be minimal at this time. A third public Interest group, the International City Managers Association (ICMA), represents 3,600 cities having a manager.

The USCM performed two surveys on the subject of energy conservation. The first went to the 800 largest cities of which several hundred indicated energy conservation activities. From these the 64 seemingly most energy conscious were recontacted by the USCM staff with a more detailed survey.

Areas of energy activity in the cities include life cycle costing, energy newsletters, seminars and workshops, carpooling for city employees, energy audits of city bulldings and reduction of lighting ... in bulldings and streets.

Among the 50 respondents to the second survey, important energy activities included: energy audits of city buildings, lighting efficiency measures, carpooling for employees (100-200 riders typically), weatherization for homeowners, and outreach to homeowners.

A list of the major cities in Energy Extension Service States that had a major conservation effort and that responded to the final survey is given in Figure 5, page 25 . 
Figure 5

EXAMPLE CITIES IN EES PILOT STATES ACTIVE IN ENERGY CONSERVATION

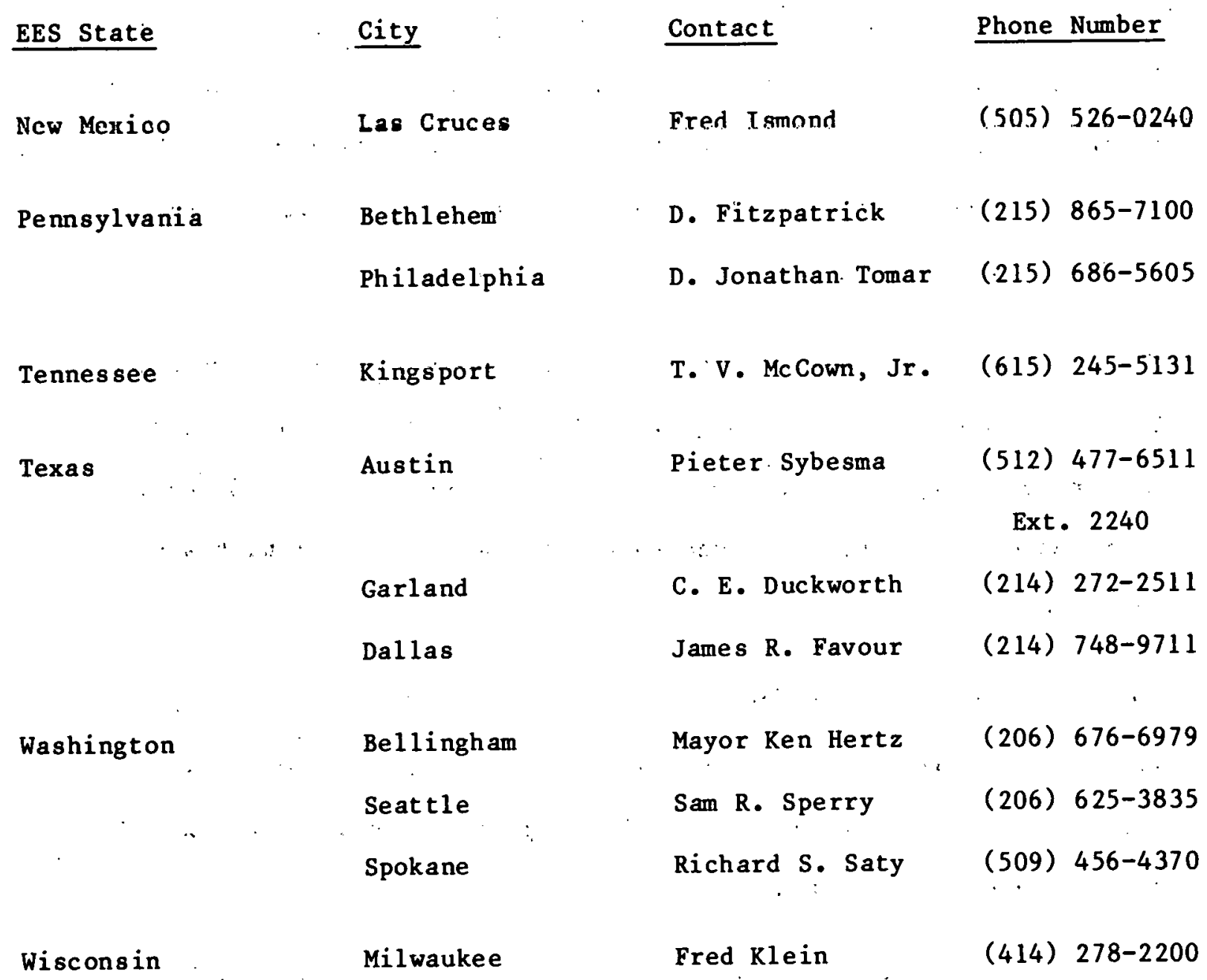


The League of Cities has established CLEO, the Committee of Local Energy officers. This is expected to be a source of more extensive energy conservation data on cities in the future. 


\section{E. PRIVATE SECTOR OUTREACH BUDGETS}

Among the many private organizations, environmentalist groups, trade associations, corporations, research laboratories and so forth, which comprise the private sector, the privately-held (but publicly regulated) utility companies are the most likely candidates to be active in significant conservation outreach activities. This is due to their enormous financial resources and the fact that their customers represent the large majority of the consumers of electrical energy and most consumers of natural gas. Whereas there may also be millions of dollars being spent by groups other than utilities, for purposes of this paper only the utilities have been surveyed.

With respect to natural gas, the American Gas Association reported the results of a survey of their members conducted in February 1977. That data, is presented in Figure 6 on page 29. Figure 6 shows gas companies active in conservation outreach activities in the EES pilot states. Three of these were surveyed by telephone, synopses of which are given at the end of Section $F$ on pages 45 through 49 . Per capita expenditures for these three gas utilities are summarized in Figure 8, page 50.

The conservation section of the proposed Presidential National Energy Act would provide for all major utilities to provide energy audits for home 
insulation and to finance the work performed by qualified application subcontractors. If this legislation is adopted, the list of utilities involved in this procedure will increase substantially.

However, in Wisconsin the Public Service Commission has required the Wisconsin Gas Company to perform free energy audits for its customers' homes. The overwhelming demand for this service has turned out to be more than the utilities resources could handle. 
Figure 6

Gas Utilities with Energy Outreach Activities

Guarantee of

EES State Active Companies

Audits.. Financing

Subcontractors

CT:

Southern CT Gas Co.

yes

no

yes

(Bridgeport)

MI

MI Consolidated

yes

yes

yes

$\therefore$ (Detroit)

Consumers Power Co.

yes

ye 8

no

(Jackson \& Detroit)

MI Gas Utilities Co.

yes

yes

yes (Monroe)

PA

Equitable Gas Co.
(Pittsburgh)

yes

no

yes

Philadelphia Electric Co. yes

*

*

(Philadelphia)

UGI Corporation

yes

(Valley Forge)

TN

United Cities Gas Co.

(Nashville)

yes

yes

yes

TX

Pioneer Natural Gas Co.

yes

yes

yes

(Amaril10)

WA

Washington Natural Gas Co. yes
(Seattle)

yes

yes

WI

Wisconsin Gas Co.

(Milwaukee)

WY

Cheyenne Light Fuel and

yes

yes

no

no

Power Co.

(Cheyenne)

*data not available 


\section{Electric Utilities' Energy Outreach}

The Edison Electric. Institute has set up the "National Energy Watch" (NEW), a residential insulation program available to each of its members. In this program the Institute provides guidance and materials for member utility companies as to how they might reach and assist the public with services ranging from information to energy audits, insulation, and in some cases, financing for homeowners. Twenty-four out of a possible 136 electrical utilities located in the 10 EES States have designated a company coordinator and are actively participating in NEW today, as follows:

\section{EES State}

AL

CT

MI

NM

PA

TN

TX

WA

WI

WY
Total Number of Electric Utilities in State

10

4

6

3

9

47

22

22

10

3

10
Number in NEW Program
1

3

1

0

6

0

6

1

6

0 
Preliminary to a more extensive survey of electric utilities, the $\ldots$ authors have sampled the outreach activities of six utilities in six EES States. Summaries of these telephone surveys appear in Section F, pages 33 through 44 .

For the six utilities contacted, per capita expenditures ranged from a low of 40 cents, for an urban utility to a high of $\$ 2.21$ for a rural utility with a very aggressive energy activity•

As these utilities were selected from a list of companies designated by. the Edison Institute as "active" In energy conservation, the reader is cautioned not to extrapolate these results to estimate average utility company expenditures.

Data on the outreach staffing payroll of 18 selected companies were obtained from the DOE/FERC Office of Public Information using the filed Annual Reports of the Electric Utilities. Results are tabulated in Figure 7, on page 32, for six of the ten EES states. Again, a wide range of outreach expenditures was seen for calendar year 1976, from a low of 20 cents per capita in Connecticut to a high of $\$ 1.94$ in Wisconsin. The average per capita energy outreach expense, according to the FERC data, is 79 cents per capita, not including advertising and media costs. This totals $\$ 42$ million for the 53.5 million citizens of the 10 EES states. 
Using the current advertising budgets of the six utilities surveyed, the average advertising expenditure amounts to 16 cents per capita per year. Thus, the total outreach budgets are estimated at 95 cents per capita.

\section{Figure 7}

Energy Outreach Staff Expenditures

by Electric Utilities

\begin{tabular}{|c|c|c|c|c|c|}
\hline State & Per & $\begin{array}{l}\text { Expenses } \\
\text { Household } \\
\end{array}$ & $\begin{array}{c}\text { Expenses } \\
\text { Per Capita } \\
\text { (Divide by 2.85) }\end{array}$ & $\begin{array}{c}\text { State } \\
\text { Population } \\
\text { (Millions) } \\
\end{array}$ & $\begin{array}{l}\text { Total } \\
(\$ 000)\end{array}$ \\
\hline $\mathrm{CT}$ & & .57 & 0.20 & 3.0 & 600 \\
\hline MI & & .85 & 0.30 & 9.1 & 2,730 \\
\hline NM & & 3.26 & 1.14 & 1.1 & 1,254 \\
\hline PA & $\therefore$ & 1.90 & 0.67 & 11.8 & 7,867 \\
\hline $\mathrm{TX}$ & & 2.76 & 0.97 & 12.2 & $.11,834$ \\
\hline WI & ; & 1.65 & 1.94 & 4.6 & 8,924 \\
\hline & & & & 41.8 & 33,209 \\
\hline
\end{tabular}


F. ELECTRIC AND GAS PRIVATE UTILITY SURVEYS

(Six electric utilities followed by 3 gas utilities)

Electric Utility, Survey $\sharp 1$

Northeast Utilities

Newington, $\mathrm{CT}$

Mr. Ralph Marrone

Manager, Techñical Services

$203 / 666-6911$

Northeast Utilịtịes Energy Management Services Department has an extensive conservation outreach activity. Eighty employees devote an estimated $25 \%$ of their time in contact with households concerned with home energy improvement, appliance efficfency, insulation, etc. The service area of the two operating susidiaries of Northeast Utilities encompasses about one million households, of which 165,000 are located in the State of Massachusetts.

The company has taken the former FEA program "RETROTECH", adopted it and renamed it "RESP" Residential Energy Savers Program. The 18 local offices of the company hold two-hour workshops for the public, teaching them to do their own energy home audits. In the past six months, 250 workshops have been held, serving more than 6,000 people. 
The company is also an active member of the Edison Electric Institute NEW conservation program, the National Energy Watch.

Insulation requirements are not being financed by the company, rather, inquiries are referred to local banks and contractors.

Energy audit questionnaires, based on Project Conserve, have been provided to 12,000 employees. Plans are to provide the same computer service to all residential customers.

Advertising for energy conservation includes both newspaper ads and "stuffers" in monthly bills.

Coordination with the Connect1cut EES office is adequate, in the opinion of management:

An estimate of the annual budget for energy outreach follows:
Advertising - newspaper
$\$ 250,000$
Advertising - stuffers (@ 1.3 cents)
200,000
Energy Audits
60,000
$25 \%$ of staff, including overhead
$1,000,000$
Total
$1,510,000$
Per Household $\$ 1.51$
Per Capita $\$ 0.53$ 
Electric Utility, Survey 非

The Detroit Edison Company

Detroit, MI

James H. Tuttle

$313 / 237-8000$

This predominately urban utility, with $1,500,000$ residential customers, has an extensive outreach effort.

The company will finance insulation jobs up to $\$ 750$ with four years to pay at low interest. In the past year, 11,000 houses were insulated under this program, but only about 1,000 customers actually required financing. Most people, when convinced that insulation would pay for itself, paid cash or arranged their own financing.

Presently, 40 marketing service representatives devote $50 \%$ of their time to conservation outreach. In September, the energy audit staff will be expanded by 29 additional people.

Advertising consists of media space and time since bills are mailed as post cards and the stuffing of envelopes, used elsewhere, is not possible in this instance.

Over 100 seminars/workshops are held annually, managed by a staff of 30 people. These serve the public, small businesses, architects, and the real estate industry. 
Recently, an energy show was held which was attended by over one million people.

Annual budget estimates for energy outreach are:

$\begin{array}{lr}\text { Advertising } & \$ 1,300,000 \\ \text { Staff } & 1,250,000 \\ \text { Total } & \$ 2,550,000 \\ \text { Per household } & \$ 1.70 \\ \text { Per capita } & . .\end{array}$


Electric Utility, Survey \#3

Philadelphia Electric Company

Philadelphia, PA

Mr. Jack Lowry

Manager, Applications Department

$215 / 841-5590$

Philadelphia Electric Company services almost 1,300,000 customers in the Philadelphia area. The energy conservation program is a comprehensive one covering improvements in building thermal performance and energy efficiency in both the use and selection of energy consuming equipment.

Advertising is conducted via television, radio, newspapers, direct mail, and personal contact. Training programs are also utilized to teach and motivate contractors, equipment suppliers, and residential customers on the advantages and techniques of conserving energy.

A Speaker's Bureau last year offered four different programs on energy conservation to school, civic, and community groups, presenting over 100 programs to an audience of over 11,000 .

The Company also offered an energy conservation education program to elementary school teachers, representing over 30,000 students.

Eight Ẹnergy Seminars were attended by almost 1300 industry members. 
Four B111 Enclosures on conservation topics were mailed to over 1,000,000 customers with more than 250,000 requesting and receiving conservation booklets on various subjects.

Energy Conservation Centers offer displays and 11terature at 13 ut1lity bill-paying centers. During 1977, 200,000 brochures were distributed.

Three Conservation Demonstration Projects which included insulation, solar energy and energy efficient appliances were held in company showrooms and a shopping center and at a solar-heated building.

In Commercial Operations, 184 employees contact customers.

An estimate of the annual energy conservation budget follows:

Advertising

Stuffers (@1.3 cents)

Staff

Workshops
$\$ 900,000$

31,000

521,000

30,000

$\$ 1,482,000$

Total

Per household $\$ 1.14$

Per capita $\$ 0.40$ 
Electric Utility, Survey 非

Texas Power and Light Company

Dallas, TX

Mr. Dudley B. Bozeman

$214 / 748-5411$

Although headquartered in a major urban area, this utility basically serves a large rural area of Texas, with a service area of about 600,000 residential customers. The company cooperates with Dallas Power and Light $(200,000$ households $)$ and Texas Electric $(500,000$ customers) in the Edison Electric Institute NEW program, calling it EOK/NOW.

In Texas Power and Light, a staff of 200 people spend $75 \%$ of their time in direct contact with the public in conservation outreach activities. This includes an extensive network of available speakers on energy. subjects in the 30 field offices.

Every month, conservation "tips" are distributed along with electric bills. A moderate amount of newspaper advertising is also conducted. Although financing of insulation retrofit is not done, an estimated 10,000 energy audits have been performed over the past ten years. Originally, these were done on a promotion basis in order to sell 
electric homes; today, the same techniques are used to reduce the high costs of electricity to consumers.

The utility coordinates with the DOE/EES pilot program.

An estimate of the annual budget for energy outreach follows:

Advertising - newspaper

Advertising - stuffers (@1.3 cents)

$75 \%$ of staff, including overhead.

Total

". Per household $\$ 6.30$

Per capita

$\$ 2.21$
$\$ 100,000$

94,000

$3,600,000$

$\$ 3,794,000$ 
Electric Utility, Survey \#5

Puget Sound Power and Light Company

Bellevue, WA

Mr. Donald Noel

$206 / 454-6363 \times 592$

Puget Sound had implemented some energy conservation projects and is planning in the very near future to do even more. The marketing department has sold several thousand hot water heater do-it-yourself insulation kits available through its 30 field offices. An energy-efficient home program holds workshops for builders and real estate firms regarding insulation standards for new construction.

As a member of the Electric League of the Pacific Northwest, starting in May 1978, a home insulation program will be instituted which will refer households to mechanical and financial sources of help. The scale of this program has not yet been decided.

The Company is planning to sell, on a break-even basis, a computerized home energy analysis.

The service area if 435,000 households. 
Budget estimates annually are as follows:

$\begin{array}{lr}\text { Radio Advertising } & \$ 90,000 \\ \text { News paper Advertising } & 52,000 \\ \text { Printing Costs (@1.3 cents) } & 33,000 \\ \text { Staff, including overhead } & \$ 50,000 \\ \text { Total } & \$ 925,000 \\ \text { Per household } \$ 2.10 \\ \text { Per capita } & \$ 0.73\end{array}$


Electric Utility, Survey $\# 6$

Wisconsin Public Service Corporation

Green Bay, WI

Mr. Paul E. ReInhardt

Manager, Marketing

414-433-1612

Under the Edison Electric Institute National Energy Watch program, 1300 Energy Efficient Homes were completed. The company has its own comprehensive conservation program, and is actively cooperating with DOE/EES in establishing Energy Information centers throughout the State.

Several thousand home energy audits have been conducted by a staff of 30 on a part-time basis. An additional eight people handle small commercial customers.

The service area is rural, with 240,000 electric households and 120,000 gas users.

Solar energy is promoted strongly. There are 16 experimental projects under study and loans for solar retrofit projects are avallable up to $\$ 2,300$.

Since bills take the form of postcards, there are no stuffers. Advertising consists mainly of TV spots. 
Annual budget estimates for energy outreach are:

Advertising

Staff

Total

Per household

Per capita
$\$ 220,000$

700,000

$\$ 920,000$

$\$ 2.56$

$\$ 0.90$ 
Gas Ut1lity, Survey \#7

Michigan Consolidated Gas Company

Detroit, MI

Ms. Mary Bradish

Mr. Len Figiel

$313 / 9.65-2430$

Under the Educational Programs Center, six professional energy speakers travel around the service area of about 800,000 residential customers conducting a variety. of programs on energy conservation. These are held at communtty centers, schools clubs, etc. In the Detroit area, and are claimed to be an extremely cost-effective outreach technique. Each speaker appears four times per week to an audience size ranging from 25 to 200. In this way, some 16,000 people are reached annually.

There are no individual home energy audit programs and since bills are postcards there are no stuffers. Special maflings are occasionally done on the conservation subject.

Michigan Consolidated was a pioneer in energy conservation, instituting one of the nation's first active home insulation programs in October 1973; over a five-year period, more than 237,000 customers acted to improve the Insulation of their own homes. An additional 39,000 contractors were hired directly by customers after being supplied with a list by the Company 
to do the insulation job. Of these, although a company financing plan was available, only 788 people took advantage of it. Terms were 20 percent down with three years to pay at an annual 12 percent interest. Booklets on How-to-Insulate are distributed at shopping centers and all of the Company's offices. The 1977 insulation figures were:

Do it Yourselfers

Contractor Jobs

Company Loans Made

Annual budget estimates are:

Special Mailings

Printing of Insulation Booklet's

Sedff

$\because \ldots \quad \because \therefore \quad \therefore$ Total

Per Household

Per Capita
56,751

13,823

271

$\$ 480,000$

15,000

350,000

$\$ 845,000$

$\$ \quad 1.06$

0.37 
Gas Utility, Survey: 非

United Cities Gas Company

Nashville, TN

Mr. Vic Papas

$615 / 244-3766$

This is a small privately-held company serving 51,000 customers of which 43,200 are residential and 7,200 are commercial.

All conservation activities are managed by a wholly-owned subsidiary, the UCG Energy Corporation, which is a profitable enterprise. In fact, in recent years profits of UCG have offset losses by the parent company. UCG performs energy audits and has the machinery to install insulation which it buys at volume at low cost. Customers of UCG Company may secure interest-free loans for attic insulation from TVA, if the customer uses electricity for heating and/or cooling.

In 1977,859 insulation jobs were completed.

They also sell spark ignition devices to replace pllot lights on hot water heaters. These sell for $\$ 120$ and have been approved by the Oak Ridge National Laboratory.

As all conservation expenses are relmbursed by customer purchases, a budget analysis would not be appropriate for this utility. 
Gas Utility, Survey 非

Wisconsin Gas Company

Milwaukee, WI

Mo. Barbara Myer

Mr. Dónald Dietrich

$414 / 2 / 6-6720$

This is the largest gas utility in the State of Wisconsin and has the most extensive energy conservation program. It serves 382,000 residential households.

A model conserving house has been built within the main building at company headquarters. This 30 -foot display is the central feature of - a "conservation center" open to the public.

The company is organizing teams of energy auditors who are presently in training. They will start with 10 and eventually expand to about 30 people.

There is also an energy hotline and a mobile display van which travels to the schools.

A total of 21 professional staff members are totally involved in energy outreach. Stuffers are not regularly provided, but quarterly consumer bulletins are mailed to customers with their bills. 
The company does not finance insulation but rather refers inquiries to the First Wisconsin National Bank which provides seven percent financing.

Finally, there is a program of cooperation with the Milwaukee County Social Development Commission, which is quite active in energy matters.

Annual budget estimates are:

Advertising - Media

Quarterly Bulletins (@2\&)

Staff, including overhead.

Audit Training

Conservation Center

$$
\text { Total }
$$

Per Household

Per Capita
$\$ 150,000$

23,000

600,000

300,000

100,000

$\$ 1,173,000$

$\$ 3.07$

$\$ 1.08$ 
Figure 8

Summary of Electric and Gas Utility Outreach Surveys

$\begin{array}{llrc}\text { State } & \begin{array}{l}\text { Type of } \\ \text { Utility }\end{array} & \begin{array}{c}\text { Number of } \\ \text { Households }\end{array} & \begin{array}{c}\text { Per Capita Outreach } \\ \text { Expenditures }\end{array} \\ \text { CT } & \text { Elec. } & 1,000,000 & \$ 0.53 \\ \text { MI } & \text { Elec. } & 1,500,000 & 0.59 \\ \text { PA } & \text { Elec. } & 1,300,000 & 0.40 \\ \text { TX } & \text { Elec. } & 600,000 & 2.21 \\ \text { WA } & \text { Elec. } & 435,000 & 0.73 \\ \text { WI } & \text { Elec. \& Gas } & 360,000 & 0.90 \\ \text { MI } & \text { Gas } & 800,000 & 0.37 \\ \text { TN } & \text { Gas } & 43,200 & \text { N/A } \\ \text { WI } & \text { Gas } & 382,000 & 1.08\end{array}$

weighted average $=\$ 0.72$ per capita 
APPENDIX A:

Selected Energy Outreach Programs for Comprehensive Program and Plan for Federal Energy Education, Extension and Information Activities (DOE/IR-005)

This appendix provides detailed information regarding each of the energy outreach programs listed in Figures 1 and 2, taken from the above document. Included for each program are an overall description, objectives, administering organization, service delivery mechanisms and the person designated in the original publication who can be contacted for further information. Budget data present in the original CPP have been deleted as they of ten represented expenditures outside of the scope of "outreach" as defined in this paper. In addition, in a few cases, the material provided in the CPP has been updated or corrected. 
CONTENTS OF APPENDIX A

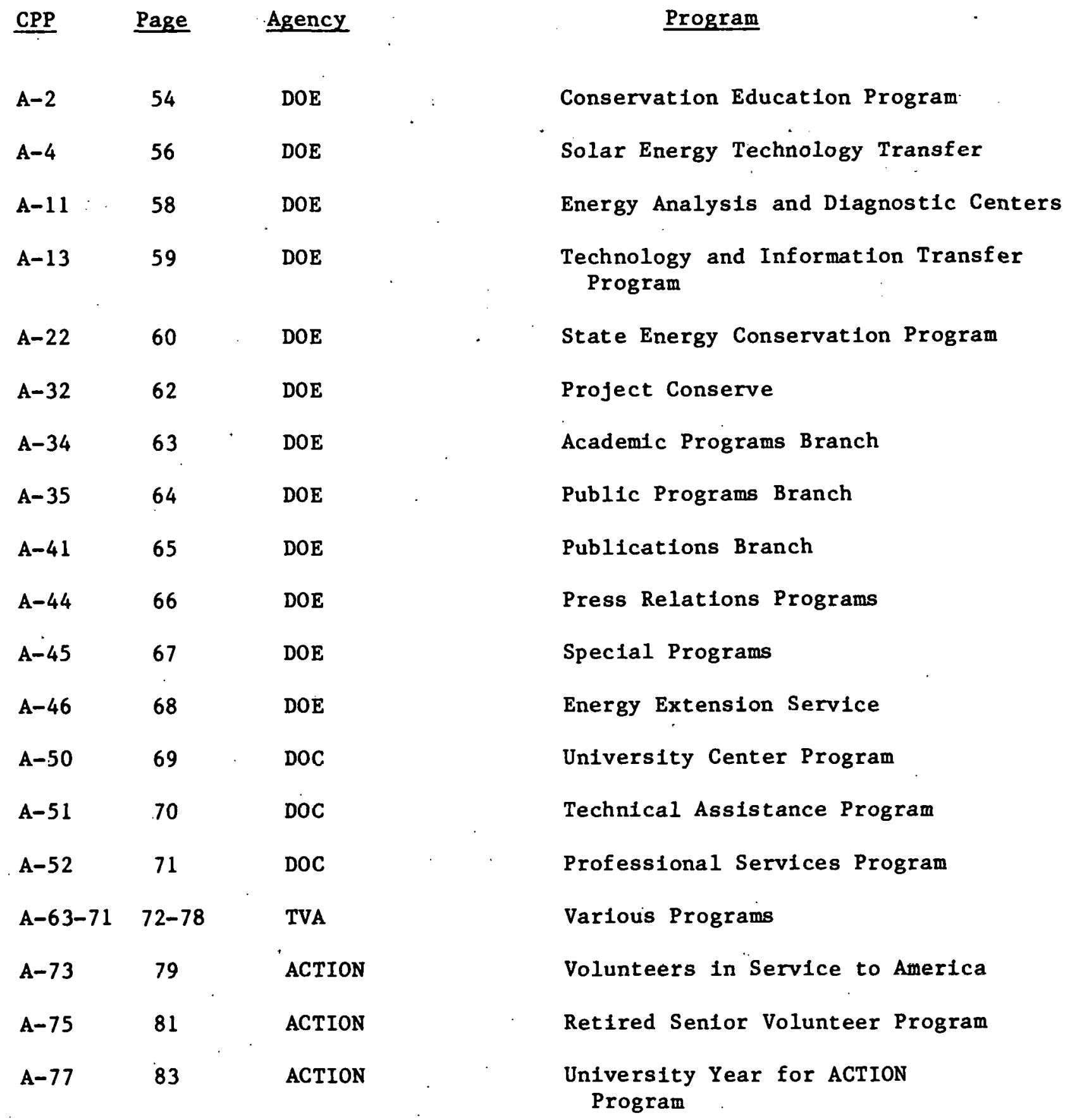




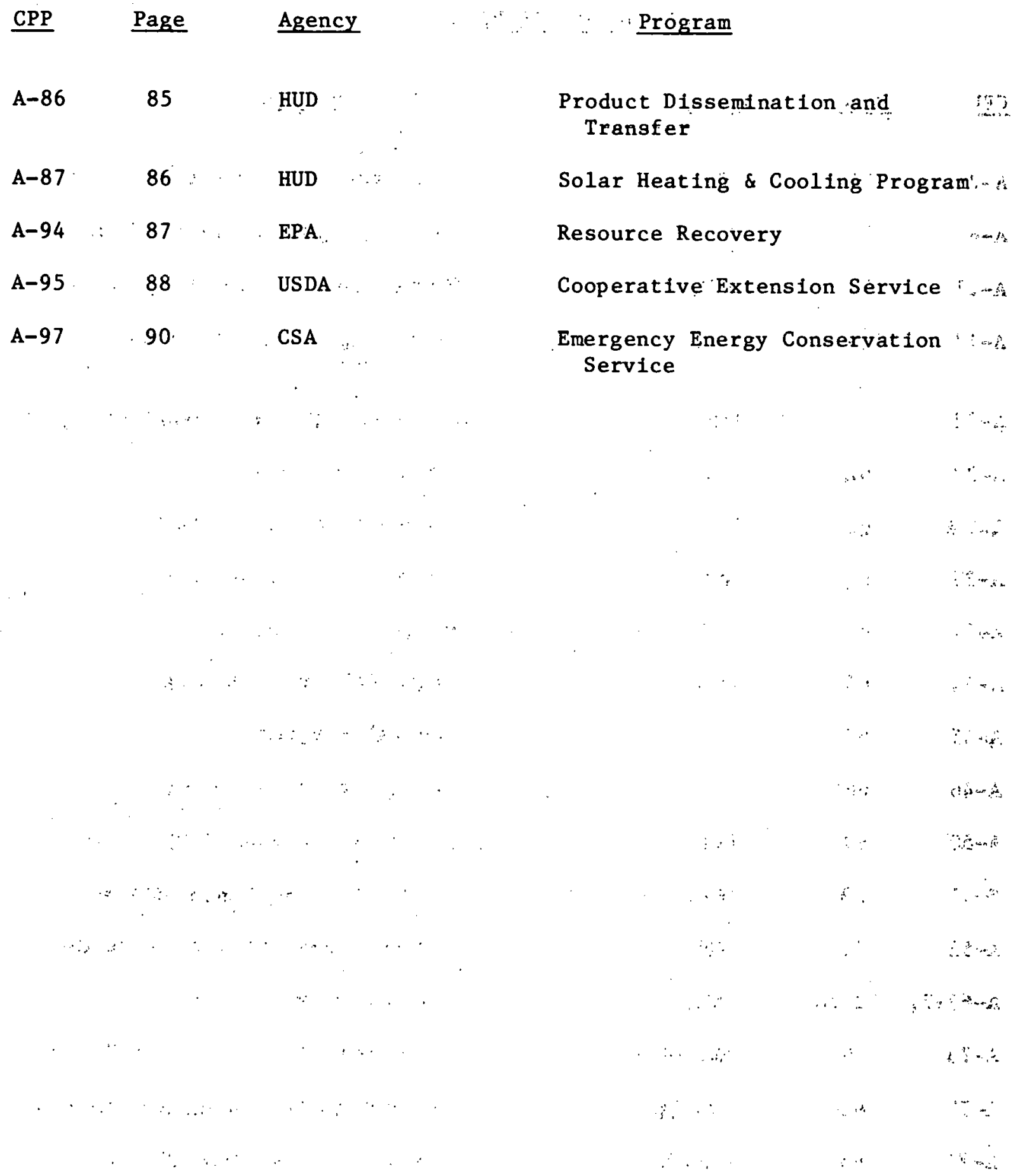


Federal Agency: Department of Energy, Conservation and Solar Applications

Program Office: Office of Marketing

Program Name: $\quad$ Conservation Education Program (A-2)

Program Contact: D. Robert Jordan

(202) $566-7916$

Description:

DOE has developed and distributed public service announcements for radio, television and print media to convey the useful information necessary for people to implement specific conservation measures. Because public service advertising is not totally adequate for reaching specific groups, DOE also is pursuing other initiatives: for example; pamphlets and booklets on home and automob1le energy conservation opportunities have been developed and distributed, a program for conservation education in primary schools, secondary schools, and Junior Colleges is under way, and citizen training workshops for adults have been conducted. DOE also has provided information support for retrofit of existing homes, specific driving conservation practices, and appliance use practices. Public opinion surveys are conducted regularly to identify appropriate areas toward which DOE should direct future efforts.

Objectives:

To continue production and distribution of public service messages on a limited basis to promote specific programs such as efficient driving, mileage guide, residential retrofit, solar applications and appliance labeling; to continue to study public opinion and behavior and test new conservation and solar programs and concepts; to obtain inclusion of energy conservation and solar units or materials in the curricula of the Nation's high schools and grade schools; and to develop marketing plans for conservation and solar programs to aid development and implementation by aligning program deliverables with market needs. 
Administrative Organization:

The office of Marketing and Education is organized into four major program areas: (1) advertising--the management of a multimedia. public service announcement program to raise awareness of the energy situation and personal options for conserving energy; (2) marketing support--aiding other conservation programs that are both new and ongoing to ensure a realistic market focus and provide marketing expertise; ( 3 ) conservation education--the development and implementation of in-school energy conservation education materials and methods; and (4) market research--survey awareness, knowledge, attitudes, and behavior of energy users toward energy conservation and solar, to provide feedback to conservation and solar programs.

Delivery Mechanisms :

Documents produced by this program are available upon request at DOE headquarters and regional offices and sent to State Energy offices and chief state school officials. 
Federal Agency: Department of Energy,

Conservation and Solar Applications

Program Office: Division of Solar Energy

Program Name: Solar Energy Technology Transfer (A-4)

Program Contact: Lawnie Taylor

Chief, Technology Transfer Branch

(202) $37.6-9146$

Description:

The Solar Energy Technology Transfer Program (STTP) is a critical link between the proven technologies of DOE's solar energy research, development and demonstration program and thelr acceptance by a solar industry. STTP, combined with barriers and incentives studies and environmental and resource assessment, is aimed at stimulating the industry market forces into an accelerated commercialization of solar energy. STTP activities consist of public education, in-service skills training, seminars, workshops, conferences, exhibits, information dissemination, and outreach functions.

Initial emphasis has been on technologies having the potential for significant industry partictpation within the 1977-78 time frame. These include solar heating of existing homes, and new and existing mobile homes; solar heating of new homes and small office buildings; solar heating and crop drying in small agricultural applications; and solar heating and cooling of commercial buildings.

Objectives:

To provide rapid response information to the needs of the building community, including builders, architects, labor unions, engineers, members of the associated financial community, concerned individuals and organizations in $\mathrm{S}$ tate and local government, professional societies and standards-setting organizations; the utility communty, including the industry, regulatiory bodies and organizations; the energy industry; and other sectors of the economy that can utflize solar technology.

Administrative Organization:

The Technology Transfer Branch, Division of Solar Energy, is responsible for the STTP program. 
Delivery Mechanisms:

The program uses "multipliers"--organizations (public and private) which have resources that can serve to multiply STTP efforts. Five DOE field labs are also used to form a nationiwide network of outreach support to the program. STTP responds to inquiries relating to all applications of solar energy, utilizing the information services provided by the National Solar Heating and Cooling Information Center (established jointly by DOE and HUD) and the DOE Technical Information Center. 
Federal Agency: Department of Energy, Conservation and Solar Applications

Program Office: Office of Business Assistance Programs

Program Name: Energy Analysts and Diagnostic Centers (EADC) (A-11)

Program Contact: Erik Haldane

(202). $377-2757$

Description:

Direct assistance to small industrial firms in auditing, analyzing, and correcting processes and practices for improving energy efficiency. (Program is in pilot phase.)

Objectives:

To aid small industrial firms in improving energy efficiency. Administrative Organization:

Program management in Office of Bustness Assistance Programs. Under. grant from DOE, University City Science Center contracts with four universities.

Delivery Mechanisms:

Universities provide audits and analyses but actual improvements are achieved either within a company or through outside assistance, not from EADC. 
Federal Agency: Department of Energy,

Conservation and Solar Applications

Program Office: Division of Buildings and Community Systems

Program Name: Technology and Information Transfer Program (A-1.3)

Program Contact: Jerry D. Duane

(202) 376-4711

Description:

Designed to develop specific communication action plans for Building and Community Systems energy conservation technologies resulting from new research; development and demonstrations.

Objectives:

To develop commercialization and utilization plans for energy conservation technologies becoming avallable from current research efforts. This involves various types of communication materials and activities such as publications, audio-visual presentations, "workshops, etc.

Administrative Organization:

Managed by the Building and Communtty Systems Division, Office of the Assistant Secretary for Conservation and Solar Applications.

Delivery Mechantsms:

The Technology and Information Dissemination Branch develops communications plans that complement the scope of the various RD\&D projects. The communications plans identify for each technical project: audiences to receive information, type of dissemination products to be developed and chains or disseminating. information. 
Federal Agency: $\because$ Department of Energy, Conservation and Solar Applications

Program Office: Office of State Grant Programs

Program Name: State Energy Conservation Program (A-22)

Program Contact: John D. Rivera

Acting Director, Office of State Grant Programs (202) 566-7442

Desçription:

The Energy Policy and Conservation Act (EPCA) of 1975 established a program of state energy conservation plans designed "to promote conservation of energy and reduce the rate of energy demand growth by implementing five mandatory program measures in addition to measures selected by a State. The five mandatory program measures would require States to:

$\therefore$ set mandatory lighting standards in non-Federal public buildings;

- set mandatory, energy-related procurement standards for State and local governments;

- set mandatory insulation standards for new and renovated buildings;

- enact a right-turn-on-red traffic law;

- promote carpools, vanpools and public transportation.

The act authorized DOE to establish guidelines and procedures for such a program and to grant financial and technical ald to $S$ tates in support of their conservation plans.

The Energy Conservation and Production Act (ECPA) amended the EPCA by adding three mandatory program measures for which a State might recelve Federal funding. These additional required programs are:

- energy audits free to homeowners and renters and at a reasonable cost to others; 
- public information on costs, savings, implementation and monitoring effectiveness for energy-saving investments;

- coordination among local, State and Federal conservation programs.

Objectives:

To reduce the rate of State energy demand growth by 5 percent of the demand projected for 1980 .

Administrative Organization:

Associate Assistant Administrator, State and Local Programs of the DOE supervises this program; the first points of contact for assistance are the local DOE regional office representatives.

Delivery Mechanisms:

Support and information is disseminated through DOE's regional offices. Grants for program implementation are awarded by the DOE Regional Administrator to the Governor's designee within each State program. 
Federal Agency: Department of Energy,

Conservation and Solar Applications

Program Office: Office of Residential and Commercial Buildings

Program Name: Project Conserve (A-32)

Program Contact: Carol Norris

(202) 566-9317.

Description:

Encourages residents of single-famlly dwellings to save up to 20 percent of the energy used to heat and cool their homes. Project Conserve I centers around a simple questionnalre on energy-use patterns to be completed by a homeowner. Data from the questionnaire are processed by a computer, and an analysis of potential improvement costs and fuel-cost savings is mailed back to the homeowner within six weeks. Each respondent receives a. personalized statement of "do-it-yourself" and contractor costs for suggested improvements, an estimate of the dollar- and energysavings potential, and the payback period for each suggested action.

In Project Conserve II, a homeowner recelves the "Home Energy Savers Workbook" in which he is shown how to make energy audit calculations himself. From these calculations, the homeowner is able to decide which home improvements are most cost-effective for his residence.

Objectives:

To achieve a 20-percent reduction in the yearly cost of fuel for participating homes.

Administrative Organization:

The Office of Conservation and Solar Applications, Office of Residential and Commercial Buildings is in charge of this program; the first point of contact for assistance is the DOE regional of $f$ ice representative. 
Federal Agency: Department of Energy, Intergovernmental and Institutional Relations

Program Office: Education Programs Division

Program Name: Acadenic Programs Branch (A-34)

Program Contact: Donald D. Duggan

(202) 376-9211

Description:

The Academic Programs Branch develops and disseminates curriculum materials, and gives grants and contracts to colleges and universities to support training activities for teachers. These activities are designed to help teachers realize the complexity of energy issues, learn sufficient technical detail about scientific, technological and social aspects of energy problems, and incorporate energy into their courses.

Objectives:

To ensure the inclusion of energy topics into school curricula.

Administrative Organization:

Operates through the Education Programs Division, Office of Education, Business and Labor Affairs.

Delivery Mechanisms:

Summer workshops and training seminars are conducted by colleges and universities, selected by annual competition. Curriculum materials developed under contract are disseminated by the Technical Information Center, Oak Ridge National Laboratory. 
Federal Agency: Department of Energy, Intergovernmental and Institutional Relations

Program Office: Education Programs Division

Program Name: Public Programs Branch (A-35)

Program Contact: Donald D. Duggan

(202) 376-9211

Description:

This program provides information and informational materials to the public through organized groups such as the"League of Women Voters.

Objectives:

To provide the public with the information it needs to make judgments about the need for energy conservation, both nationwide and in their personal lives. Additionally to provide the public with information concerning the Nation's energy problems and options, and the role of the public in energy policy development.

Administrative Organization:

Managed by the Education Programs Division, Office of Education, Business and Labor Affairs.

Delivery Mechanisms:

Grants and contracts with organized membership groups which are selected annually on a competitive basis. 
Federal Agency: Department of Energy, Intergovernmental and Institutional Relations

Program Office: Office of Public Affairs

Program Name: Publications Brạch (A-41)

Program Contact: John M. Sullivan

(202) 353-4354

Description:

Develops publications reflecting both DOE programs and general scientific concepts in the energy field for the general public. Over 10 million pamphlets, folders, booklets, and posters were distributed during the past year.

Objectives:

To reach as wide an audience as possible with information that anticipates topics of public interest and provides general background on energy for the average citizen.

Administrative Organization:

Reports to the Director, Editorial Services Division, Office of Public Affairs.

Delivery Mechanisms:

Through the Office of Public Affairs. 
Federal Agency: Department of Energy, Intergovernmental and Institutional Relations

Program Office: Office of Public Affairs

Program Name: Press Relations Programs (A-44)

Program Contact: Alfred P. Alibrando

(202) 376-4055

Description:

$\because$ Develops and carries out agencywide public information programs through the use of news releases, fact sheets, statements, press briefings, interviews (newspaper, magazine, radio, television), response to news queries, special articles, and presentations.

objectives:

Widest possible dissemination of information regarding DOE programs and activities.

Administrative Organization:

Program management by the Director, Press Services Division, Office of Public Affairs.

Delivery Mechanisms :

Office of Public Affairs. 
Federal Agency: Department of Energy, Intergovernmental and Institutional Relations

Program Office: Office of Public Affairs

Program Name: $\quad$ Special Programs (A-45)

Program Contact: Pete Keay

(202) 566-7104

Description:

Develops and carries out agencywide information programs through the scheduling of agency speakers, special minority information. programs aimed at Black and Hispanic groups.. Also answers general public inquiries received through the mail. Schedules special events such as dedications, ground breakings, and openings of laboratories, and research projects. Also responsible for general research activities in support of the public appearance of top DOE officials.

Ob ject ives :

The widest possible dissemination of information regarding DOE activities and programs.

Administrative Organization:

Director of Special Programs Division.

Delivery Mechanisms:

The mass media, trade associations, civic and minority groups, personal contacts, and written answers to mail inquiries. 
Federal Agency: Department of Energy,

Assistant Secretary for Institutional Relations

Program Office: Office of Intergovernmental Affairs

Program Name: Energy Extension Service (A-46)

Program Contact: Judith Liersch

(202) 252-6240

Description:

The Energy Extension Service is a program to implement energy conservation measures and to encourage the use of renewable energy sources. The program works through the states, who design and implement activities for assisting energy consumers to adopt energy-efficient practices and technologies. As present, there is an 18-month pilot program involving grants of about $\$ 1.1$ million each to 10 states. Grants of $\$ 30,000$ have also been made to the remaining states and territories to observe the progress of the pilot states and to prepare for participation in a nationwide program.

Objectives :

Encourage individuals and small establishments to reduce energy consumption and convert to renewable energy sources.

Provide feedback to DOE and other decisionmakers regarding "institutional and technological barriers to the adoption of energy-saving measures.

Help reduce the impact of fuel shortages and price increases on small consumers by developing a creditable technical assistance and information program that facilitates the adoption of energysaving measures.

Administrative Organization:

The DOE Energy Extension office serves as the central administrative office for the 10 pilot programs.

Delivery Mechanisms :

Services planned by most of the pilot states include energy audits; seminars and workshops; information dissemination to residential dwellers; and energy hot lines. 
Federal Agency: Department of Commerce, Economic Development Administration

Program Office: Office of Technical Assistance

Program Name: University Center Program (A-50)

Program Contact: Glenn Fatzinger

(202) $377-4637$

Description:

An action-oriented program providing management and technical assistance services to business and industry. Twenty University Centers are presently operating and several more are under consideration.

Object ives :

To help business and industry increase productivity, improve management, and improve and expand operations.

Administrative Organization:

Managed by the Office of Technical Assistance.

Delivery Mechanisms :

The 20 Center directors and staff and numerous specialists work directly with clients. 
Federal Agency: Department of Commerce,

Economic Development Administration

Program Office: Office of Technical Assistance

Program Name: Technical Assistance Program (A-51).

Program Contact: Alfred Diamond

(202) $377-4288$

Description:

Provides assistance to State and local governments, and public and private nonprofit organizations in the form of feasibility studies and comprehensive studies of an area's human (and other) resources and how to utflize them most effectively. Furnishes missing know-how, technical information, and counseling; conducts pilot or demonstration projects; supports nonprofit organizations working to produce jobs and Improve economic opportunities; also supplies grants-in-aid (with a 25 percent match by applicant) or contracts to applicants.

Objectives:

To stimulate economic growth, generate employment opportunities, save threatened jobs, and improve levels of living in economically depressed areas.

Administrative Organization:

Managed by the office of Technical Assistance and small staffs in six EDA Regional offices.

Delivery Mechanisms:

Contracts to consultants to furnish the necessary assistance to applicants.

Grants to government agencies and public and private non-profit organizations. 
Federal Agency: Department of Commerce, Economic Development Administration

Program Office: Office of Development Organizations

Program Name: $\quad$ Professional Services Program (A-52)

Program Contact: Bernhard Richert

(202) $377-4510$

Description:

This program provides for employment of energy experts to assist local governments in the development of energy conservation programs, in effective planning for energy use and development, and in assisting business and industry to effectively meet their energy needs.

Objectives :

To aid local communities and their industries in energy conservation and effective energy utilization.

Administrative Organization:

Managed by the Office of Development Organizations.

Delivery Mechanisms :

Professional specialist on individual Economic Development District staffs. 
Federal Agency: Tennessee Valley Authority

Program Office: Office of Power, Division of Power Utilization, Conservation and Energy Management Branch

Program Name: Certified Electric Heat Pump Installation Program (A-63)

Program Contact: James W. Ward

(615) $755-3750$

Description:

A heat pump program designed by TVA and adopted by a number of power distributors to increase the number and quality of heat pump installations in the TVA service area. Local heat pump dealers and their employees attend heat pump. Installation classes taught by the TVA and arranged by local power distributors; specialists from the major manufacturers provide training in heat pump servicing; and power distributors certify the dealers enrolled in the program based on inspections of their installations. TVA has developed a folder, the Certified Electric Heat Pump Installation Program, to explain the program to consumers. A heat pump buying guide is also available.

Objectives:

To help eliminate three problems that have damaged the heat pump's reputation in the past: faulty units, poor installation, and

inadequate servicing.

Administrative Organization:

Managed by the Division of Power Utilization, Conservation and Energy Management Branch.

Delivery Mechanisms:

Local power distributors and major manufacturers in cooperation with TVA staff. 
Federal Agency: Tennessee Valley Authority

Program Office: 'Office of Power, Division of Power Utilization, Conservation and Energy Management Branch

Program Name: Home Insulation Program for the TVA Area (A-64)

Program Contact: W. C. Whisenant, Coordinator

Home Insulation Program

(615) 755-3746

Description:

The program is designed to promote energy conservation and the more efficient utilization of electricity by encouraging all residential consumers to have adequate insulation. The program provides energy surveys and recommendations for all residential consumers and interestfree capital to cover the cost of attic insulation in dwelling units that heat or cool with electricity. The reduction in electric energy use by the participants will permit savings in capacity and fuel costs, thereby benefiting all consumers of TVA power through lower rates than would otherwise be required. The power distributors and TVA will achieve an estimated reduction in peak demand of 400-500 MW during the heating season, resulting in lower capacity requirements and in TVA's using less high-cost oil for turbines and high-cost purchased power. These savings are estimated at 25 million per year upon completion of the program. Approximately 750,000 dwelling units will have their attlc insulation upgraded to at least an $R-19$ level.

Objectives:

To reduce' electrical energy use by making electrical heated and/or cooled dwelling units more efficlent, thus permitting lower rates to TVA consumers.

Administrative Organization:

Managed by the Division of Power Utilization, Conservation and Energy Management Branch.

Delivery Mechanisms :

TVA staff in cooperation with local power distributors. 
Federal Agency: Tennessee Valley Authority

Program Office: Office of Power, Division of Power Utilization, Conservation and Energy Management Branch

Program Name: Consumers Communications Service for Distributors of. TVA Power $(A-65)$

Program Contact: James W. Ward

(615) $755-3750$

Description:

Prepares and produces advertising, publicity, and pamphlet material on energy conservation and electrical safety for use by the 160 distributors of TVA-generated power.

Objectives:

To reach effectively the ultimate consumers of TVA power with information on energy conservation and electrical safety. In addition, to fulfill our partnership responsibilities with the distributors of TVA power for consumer communications.

Administrative Organization:

Managed by the Division of Power Utilization, Conservation and Energy Management Branch.

Delivery Mechanisms:

Material is furnished to the five Office of Power Utilization district offices, who deliver or send it to each TVA power distributor. 
Federal Agency: Tennessee Valley Authority

Program Office: $i$. Office of Power, Division of Power Utilization, Conservation and Energy Management Branch

Program Name: . Display Service for Distributors of TVA Power (A-66)

Program Contact: James W. Ward

(615) $755-3750$

\section{Description:}

Designs and constructs displays, exhibits, posters, and other material for use by the 160 distributors of TVA-generated power.

Objectives:

To reach effectively the ultimate consumers of TVA power with information on energy conservation and electrical safety.

Administrative Organization:

Managed by the Division of Power Utilization, Conservation and Energy Management Branch.

Delivery Mechanisms:

Power distributor offices; sometimes the five OPU district offices are used to deliver energy conservation and electrical safety information to interested consumers. 
Federal Agency: Tennessee Valley Authority

Program Office: Office of Power, Division of Power Utilization, Conservation and Energy Management Branch

Program Name: End-Use Electric Energy Management Program (Commercial and Industrial Loads) (A-67)

Program Contact: James W. Ward

(615) $755-3750$

\section{Description:}

The program encourages the application of effective management decisions to help check and control the amount of energy used in business and industry. Based on energy value and life-cycle concepts, the program can increase the energy efficiency of any business. Meetings are held with business and industry, civic clubs, and educational institutions. A brochure entitled "The Electric Energy Management Program" covers the required steps in setting up such a program.

Objectives:

To reduce business and industry needs of power and energy to the minimum level required to efficiently produce a product or service.

Administrative Organization:

Managed by the Division of Power Utilization, Conservation and Energy Management Branch.

Delivery Mechantsms:

TVA commercial and industrial engineers from the Electrical Demonstration Branch, Division of Power Utilization, provide information to businesses and educational institutions. 
Federal Agency: Tennessee Valley Authority

Program Office: Office of Power, Division of Power Utilization, Conservation and Energy Management Branch

Program Name: Residential and Agricultural Programs (A-69)

Program Contact: James W. Ward

(615) $755-3750$

Description:

Programs on energy education, including sources of electricity, expected supply, and costs. Varied programs on total energy use with emphasis on residential heating and cooling appliances, and agricultural application. The program trains educators at all levels (1ncluding colleges, universities, vocational technical schools and grade schools) and trains agricultural extension personnel, community action agencies, Scouts, home builders, senior citizens and other groups. Direct consumer contracts are made through civic clubs, community organizations, professional groups, special interest groups, fairs, camps, and shopping centers. Information is disseminated through workshops, seminars, demonstrations, displays, exhibits, tours, discussion, lectures, and distribution of publications.

Ob'jectives:

To reach all residential and agricultural consumers with energy consumption information geared to their needs; to stop all waste of electricity; and to maintain and/or improve the quality of life through efficient uses of electricity and other resources.

Administrative Organization:

Managed by the Division of Power Utilization, Conservation and Energy Management Branch.

Delivery Mechanisms:

Information is provided by TVA branch and district staff and avallable staff of power distributors. (Approximately 50 percent of the 160 power distributors have personnel responsible for energy education.) 
Federal Agency: Tennessee Valley Authority.

Program Office: Office of Power, Division of Power Utilization, Conservation and Energy Management Branch ' $\because$ "

Program Name: The Super Saver Electric Home Program (A-71)

Program Contact: James W. Ward

(615) $755-3750$

Description:

A program designed to encourage the construction of residential dwelling that are energy efficient. Buflding sections demonstrations, props, slides, brochures, and use of advertising media help convey the message.

Objectives:

To siress conservation of energy as part of the National goal to achieve energy independence; to help consumers minimize electric; utility costs; and to work with builders in sharing proven construction techniques that utilize conventional insulating materials.

Administrative Organization:

Conservation and Energy Management Branch of TVA's Division of Power Utilization.

Delivery Mechanisms:

TVA staff meet with bülders, contractors, civic, and consumer groups. 
Federal Agency: ACTION

Program Office: Domestic Operations

Program Name: :Volunteers In Service To America (VISTA) (A-73)

Program Contact: Margery Tabankin

Director, VISTA \& ACTION Education Programs

(202) 254-7376

Description:

VISTA Volunteers perform a variety of services and act as catalysts , for local community involvement in the human need sectors of health, nutrition, energy conservation, economic development, community services and legal rights. In energy conservation, VISTA Volunteers assist in winterization and insulation, in education efforts to teach energy-saving methods, in job training and placement in solar construction. In legal areas VISTA assists with utility rates, pollution standards, etc.

Objectives:

To strengthen and supplement efforts to eliminate poverty and poverty-related human, soctal, and environmental problems in the United States by encouraging and enabling persons from all walks of life and all age groups to perform meaningful and constructivé volunteer service in agencies, institutions, and other situations.

Administrative Organization:

The director of VISTA and ACTION Education Programs is responsible to the associate director for Domestic and Ant1-Poverty Operations, and administers VISTA and the ACTION Education Programs (University Year for ACTION, Youth Challenge Program and the National Student Volunteer Program). ACTION and VISTA headquarters are in Washington, D.C. There are 10 Regional Offices and State Offices serving all 50 States, the District of Columbia, Puerto Rico and the Virgin Islands . 
Delivery Mechanisms:

VISTA provides nationally-recruited volunteers and locallyrecruited volunteers through its grant mechanism. Volunteers are full-time and serve one-year terms in public or private nonprofit organizations. ACTION State offices assist potential sponsors in the development and maintenance of VISTA projects. 


\author{
Federal Agency: ACTION \\ Program Office: Older Americans Volunteer Progràms (OAVí) \\ Program Name: Retired Senior Volunteer Program (RSVP) (A-75) \\ Program Contact: Helen Kelly \\ Deputy Associate Director for Older Americans Volunteer \\ Programs
}

(202) $254-7310$

Description:

RSVP volunteers perform a varlety of services to meet local community needs in areas such as health, education, community services, and energy conservation. Volunteers in the energy conservation field are involved in activities such as cloud seeding, teaching energy conservation courses, providing advice on home insulation, and monitoring environmental projects. ACTION provides grant funds on a cost-shared basis to local sponsors to operate local RSVP projects. Recruitment and placement of volunteers are done at the local level. RSVP volunteers serve in public and private nonprofit institutions as well as proprietary nursing homes.

Objectives:

To create meaningful volunteer opportunities for persons age 60 and over to participate more fully in the life of their communities or nearby communties through volunteer service.

Administrative Organization:

The director of Older American Volunteer Programs is responsible to the associate director of ACTION for Domestic and Anti-Poverty Operations, and administers RSVP and two other volunteer programs for older Americans: the Foster Grandparent Program (FGP) and the Senior Companion Program (SCP). ACTION has its national headquarters in Washington, D.C., with 10 Regional and State offices serving all 50 states. 
Delivery Mechanisms:

ACTION Reglonal and State offices handle initial processing of grant applications from public and private nonprofit agencies and, with OAVP staff, provide technical assistance to OAVP and sponsors. 
Federal Agency: ACTION

Program office: VISTA/ACTION Education Programs

Prógram Name: University Year for ACTION Program (UYA) $\left(A^{\prime}-77\right)$

Program Contact: Margery Tabankin

Director, VISTA \& ACTION Education Programs

(202) 254-7376

Description:

Designed to give college student volunteers the opportunity to provide services on a full-time, full-year basis, to poverty communities across the U.S., and to recelve academic credit for these services. In the area of energy, volunteers are involved in home weatherization programs, cost-effectiveness of solar energy techniques, preparing energy conservation appraisals for homes, and conducting energy conservation workshops.

Objectives:

Provide effective manpower to work on poverty problems; combine communtty service and service learning in an integrated one-year project; encourage university involvement in local poverty communities; administer volunteer projects at the local level using universities; and institutionalize the UYA goals at participating schools. Potential sponsors submit applications for grants to the nearest State Program Office.

Administrative Organization:

ACTION is a Federally-funded, national independent agency with the national headquarters office located in Washington, D.C., 10 Regional Offices across the U.S., and State Program Offices, serving all 50 states, the District of Columbia, Puerto Rico, and the Virgin Islands. 
Delivery Mechanisms :

Potential sponsors receive technical assistance from the state Program director or officer; proposals are then submitted by colleges and universities to the Regional office for review for compliance with ACTION guidelines. 
Federal Agency: Department of Housing and Urban Development

Program Office: Office of Policy Development and Research

Program Name: Product Dissemination and Transfer (A-86)

Program Contact: Heather Aveilhe

Director

(202) 755-5548

Description:

Disseminates information on energy-saving techniques to the general public and stimulates public awareness of all HUD research activities.

Objectives:

To increase the utilization of all HUD-sponsored research

by industry, state and local government, and the public.

Administrative Organization:

Office of Policy Development and Research.

Delivery Mechanisms:

The Product Dissemination and Transfer Program uses private firms and the GPO to produce and distribute radio and television spots, public service announcements, and publications. 
Federal Agency: Department of Housing and Urban Development

Program Office: Office of Policy Development and Research, Division of Energy, Building Technology and Standards

Program Name: Solar Heating and Cooling Program (A-87)

Program Contact: David C. Moore Program Manager (202) $755-5574$

Description:

Joint responsibility with DOE for a residential demonstration. program investigating practical applications of solar heating and cooling.

Objectives:

To encourage the use of solar technology in the general housing market.

Administrative Organization:

Division of Energy, Building Technology and Standards, Office of Policy Development and Research.

Delivery Mechanisms:

HUD's Solar Heating and Cooling Program includes such activities as residential demonstrations in which solar equipment is installed in new and existing dwellings; development of performance criteria and certification procedures for solar heating and cooling equipment; market development efforts encouraging rapid and widespread acceptance by housing industries of solar technologies; and dissemination of demonstration and market development results, including the National Solar Heating and Cooling Information Center. 


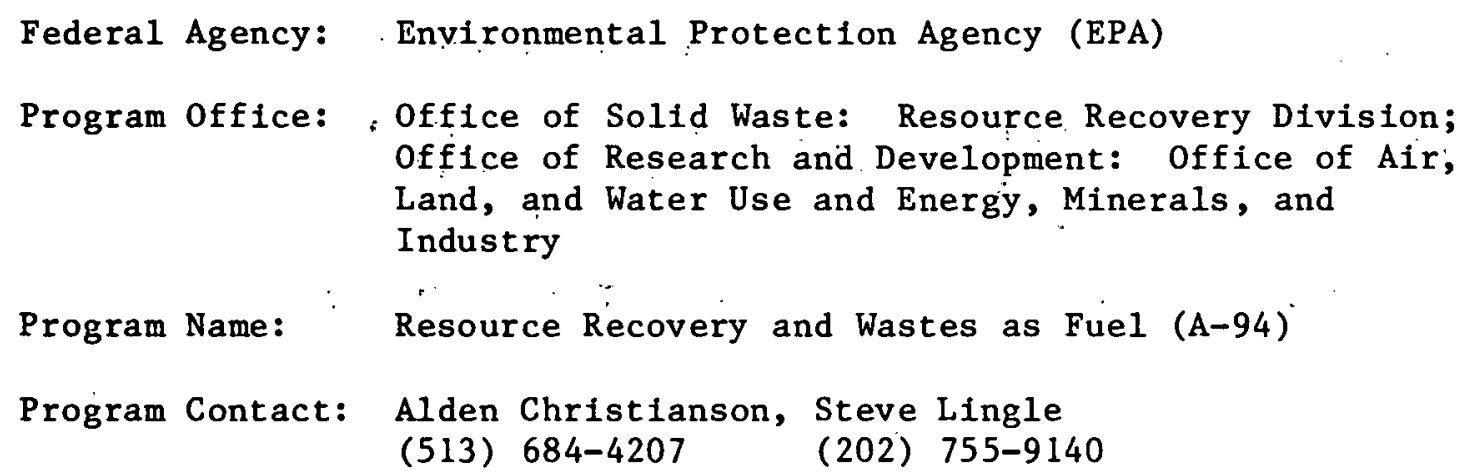

Description:

Under the Resource Conservation and Recovery Act of 1976, EPA evaluates, develops, demonstrates, and aids in the commercialization of technologies for resource recovery and the use of wastes as fuel. These technologies can serve as alternatives to the disposal of solid wastes in landfills.

Administrative Organization:

The Resource Recovery and Wastes as Fuel Programs are administered by three offices within EPA: the Resource Recovery Division in the Office of Solid Waste; the Office of Air, Land, and Water Use in the Office of Research and Development; and the Office of Energy, Minerals and Industry in the Office of Research and Development.

Delivery Mechanisms:

Research and development contracts and grants, and technical reports are provided by the Office of. Research and Development to the technical community, technical assistance, manuals, and pamphlets are provided-to State and local governments, community groups, and businesses by the office of Solid Wastes and regional solid waste offices. 
Federal Agency: Department of Agriculture

Program Office: Extension Service

Program Name: Cooperative Extension Service--50 States, Virgin Islands, Guam, Puerto Rico and District of Columbia (A-95)

Program Contact: Dr. Charles Beer

(202) 447-4387

Description:

The Cooperative Extension Service is a nationwide informal educational organization of 16,000 employees jointly supported by Federal, State and local funds. It operates programs in 3150 counties throughout the Nation. Its objective is to help both rural and urban people acquire new knowledge and skills whereby energy-saving practices can be effective to reduce our present rate of use and waste. Current programs in energy conservation have been designed to reach farm families, nonfarm rural residents, communities, urban residents, farm, commodity and related organizations dealing with agribusiness services.

Energy conservation programs are strongly emphasized along with our major program efforts in agriculture, marketing, conservation, home economics, community development and 4-H youth development. Every State Cooperative Extension Service is providing programs emphasizing those practices which conserve energy in homes, on farms and related businesses.

Currently, Cooperative Extension Services have been engaged to carry out Energy Extension Service programs funded by DOE in 7 of the 10 pilot states.

\section{Objectives:}

To educate and assist rural and urban residents to identify and solve problems directly affecting their welfare. 
Administrative Organization:

The Cooperative Extension Service is operated in each state, Puerto Rico, Virgin Islands, Guam and the District of Columbia under the Smith-Lever Act of 1914. The first point of contact is at the local county office of the Cooperative. Extension Service usually located at the county seat of government. County staff are professionally trained and provide technical assistance, program guidance, demonstrations to interpret results of research from land-grant universities, USDA and other reliable public and private resources. Programs are jointly sponsored by Federal, State and local governments.

Delivery Mechanisms:

The Cooperative Extension Service is an outreach function of the USDA and the State land-grant colleges. The local county staff with the aid of local lay advisory committees determine local program needs. County agents are supported by a specialist staff technically trained in a variety of disciplines such as agriculture, engineering, forestry, home economics, education, health, social sciences, etc. Land-grant universities have: appointed special task forces from several disciplines to deal with both research and extension capabilities in energy conservation programs. 
Federal Agency: Community Services Administration

Program Office: Office of Community Action

Program Name: Emergency Energy Conservation Services (A-97): .

Program Contact: Richard M. Saul

Energy Coordinator

(202) $254-5460$

Mary Ann Mackenzie

(202) 254-5047

Description:

Low-income individuals and families (including the elderly and the near-poor) participate in programs that promote energy conservation and seek to lessen the impact of.high energy cost. Major components of the programs include weatherization; crisis intervention assistance in the forms of grants and payment guarantees, mediation with utility companies or fuel suppliers and financial counseling; consumer information, education, and legal assistance; projects designed to address the energy-related increased cost of transportation to the poor making maximum use of existing transportation resources; and development and application of alternate energy sources technologies, such as solar and wind power or methane digesters, and projects in small farm technology to assist lowincome farmers. A major project funded by CSA is the National Center for Appropriate Technology, located in Butte, Montana, and dedicated to the development and support of locally centered technologies appropriate to the needs and resources of low-income people and communities.

Objectives:

To promote energy conservation and lessen the impact of high energy costs on low-income individuals and families; to develop communitybased programs to deal with energy-related problems; to mobilize resources within the state and community to help the poor deal with the energy crisis through innovative community structures and technologies appropriate to their needs and resources; and to conduct. advocacy programs to assist the poor in public, admintstrative, and legal proceedings involving energy costs, energy policy, and rate regulations. 
Administrative Organization:

$\mathrm{CSA}^{\prime}$ 's energy programs are coordinated by $\mathrm{CSA}^{\prime}$ s office of Community. Action which is assisted by an energy planning committee composed of representatives from operating programs and regional and state offices. Operating programs are funded through 10 Federal regional offices, each of which has an Energy Coordinator responsible for training and technical assistance functions, program guidance, reporting and quality control. Research, demonstration and evaluation activities are funded through Headquarters.

Delivery Mechanisms:

This program is carried out by local community action agencies (CAA) and state offices of economic opportunity. There are 900 local programs, covering approximately 90 percent of the Nation's counties. In 19 States, funding is through State economic opportunity offices; in the balance, funds go directly to local agencies. Each funded energy program has a project advisory committee composed of low-income persons and. representatives from local governments, resource agencies, local public utility companies, and local fuel dealers. The $110,000 \mathrm{CAA}$ staff members are trained in a variety of outreach program activities. 